\title{
Types of 'reticulin' antibodies detected in human sera by immunofluorescence
}

\author{
MARIO RIZZETTO ${ }^{1}$ AND DEBORAH DONIACH ${ }^{2}$ \\ From the Department of Immunology, The Middlesex Hospital Medical School, London
}

SYNOPSIS Reticulin antibodies have been classified by immunofluorescence into five types reacting with distinct antigens of intra- and extracellular components in mesenchyme. Two types of fibrillar antigens can be distinguished on the basis of the staining patterns, anatomical distribution, and species specificity. A third antibody reacts with either small fibres, amorphous proteins, or mucopolysaccharides lining the hepatic sinusoids (ground substance antigens). In addition, at least two kinds of intrasinusoidal cells show cytoplasmic fluorescence, ie, Kupffer cells and glass-adherent, blood-borne cells antigenically related to peritoneal macrophages. Some sera may contain antibodies reacting with sinusoidal endothelial cells though this has not yet been proven.

It has been confirmed that all these distinct antibodies related to reticulin antigens are most frequent in dermatitis herpetiformis and coeliac disease, but they are also found with increased frequency in chronic heroin addicts and in rheumatoid and Sjögren's syndromes. About $5 \%$ of normal individuals had such antibodies and no significant increase could be demonstrated in autoimmune disorders or in liver cirrhosis. The antibodies appear to be stimulated by bacterial or nutritional antigens and are likely to represent anamnestic responses rather than direct cross reactions with a multiplicity of foreign antigens.

The use of rat tissues for immunofluorescence with human sera has shown a variety of staining patterns in relation to mesenchymal structures in the liver, kidney, and other organs. Some of the antibodies react with connective tissue fibres and ground substances and others with cytoplasmic components of reticuloendothelial cells. Many sera, however, appear to contain mixtures of antibodies and stain cells, fibres, and ground substance in various combinations. These reactions have been called reticulin antibodies owing to the similarity with silver reticulin stains employed in conventional histology. They are of clinical interest in view of their association with coeliac disease, dermatitis herpetiformis (Seah, Fry, Hoffbrand, and Holborow, 1971a), and Crohn's disease (Alp and Wright, 1971; Seah, Fry, Holborow, Rossiter, Doe, Magalhaes, and Hoff brand, 1973).

In our experience these disorders are associated with several immunofluorescent appearances and in this paper we attempted to separate the reactions 'Present address: Department of Gastroenterology, Ospedale Mauriziano, Turin, Italy.

'Reprint requests to D. Doniach, The Middlesex Hospital, London W1.

Received for pub lication 31 July 1973. into identifiable patterns and to assess the occurrence of each of these in other diseases. In addition experiments were made to identify the intrasinusoidal reticuloendothelial cells reacting with different sera.

\section{Materials and Methods}

\section{PATIENTS' SERA}

The frequency of different fluorescent reticulin patterns was assessed on 3628 sera from patients with a wide variety of pathological conditions which also included 50 cases of coeliac disease (kindly given by Professor Jack Hobbs), 36 cases of dermatitis herpetiformis (received from Dr A. Ajdukiewicz), 75 chronic heroin addicts (tested for Dr Jeanne Kreek), and 360 cases of various hypersensitivity reactions to a number of drugs (tested for $\mathrm{Dr}$ E. S. K. Assem), as shown in table I. In addition, the incidence of strong reactions was evaluated in 8000 sera sent to the laboratory in the past 12 months.

SEROLOGICAL METHODS

Unfixed $5 \mu$ cryostat sections of human thyroid and stomach and rat liver and kidney were used. For 


\begin{tabular}{|c|c|c|}
\hline Disease & No. Patients Tested & Percentage Positive Reactions \\
\hline Dermatitis herpetiformis & 36 & 47 \\
\hline Coeliac disease & 50 & 44 \\
\hline Chronic heroin addicts & 75 & 20 \\
\hline Sjögren's syndrome & 29 & 17 \\
\hline Myasthenia gravis & 18 & 16 \\
\hline Vitiligo and alopecia & 26 & 11 \\
\hline Rheumatoid arthritis/polyarthritis & 294 & 10 \\
\hline Other collagen disorders (SLE/dermatomyositis/spondylitis/some indefinite) & 185 & 7 \\
\hline Thyroid autoimmune disease (thyrotoxicosis, Hashimoto, myxoedema) & 443 & 9 \\
\hline Thyroid non-autoimmune (all other goitres) & 139 & 5 \\
\hline Autoimmune gastritis (PA/GPC $+/ \mathrm{B}_{12}$ deficient) & 114 & 4 \\
\hline Addison's disease & 25 & 8 \\
\hline 'Autoimmune' liver diease ( $\mathrm{PBC} / \mathrm{ACH}$ or crypto with autoantibodies) & 328 & 3 \\
\hline Non-autoimmune liver disease & 714 & 3 \\
\hline Drug hypersensitivity & 360 & 6 \\
\hline Miscellaneous hospital patients & 643 & 8 \\
\hline Healthy subjects & 149 & 4 \\
\hline Total & 3628 & \\
\hline
\end{tabular}

Table I Overall incidence of immunofluorescent reactions with three types of 'reticulin' fibres and two types of liver sinusoidal cells in various diseases

$\mathbf{P B C}=$ primary biliary cirrhosis; $\mathbf{A C H}=$ active chronic hepatitis; $\mathrm{PA}=$ pernicious anaemia; $\mathrm{GPC}-\mathrm{Gastric}$ parietal cell fluorescence.

special experiments livers from starved rats, pig, beef, lamb, rabbit, and mouse were tested, as well as various other rat tissues and human organs obtained at necropsy or operations. The standard sandwich technique was employed with FITC conjugated antihuman-Fab, and monospecific conjugates of antisera to the three main immunoglobulin classes and beta ${ }_{1} \mathrm{c}$. All sera were tested at 1:10 dilutions and positive sera were titred to endpoint in doubling dilutions. Storage at $-20^{\circ}$ for up to two years did not affect the reactions, although sera were usually tested when received.

\section{FIXATION EXPERIMENTS}

Fixation of cryostat sections was tried in ether, acetone, ethanol, $1 \%$ formalin, and $1 \%$ glutaraldehyde for 10 and 30 minutes at $4^{\circ}$.

\section{LIVER PERFUSION AND SEPARATION OF MESENCHYMAL CELLS}

Livers were perfused with cold Hank's Ca-free solution until blanched to free the sinusoids of circulating blood cells. Hepatic reticuloendothelial cells were loaded with carbon by injecting $10 \mathrm{mg}$ of a colloidal suspension in $2 \mathrm{ml}$ saline intraperitoneally 24 hours before removing the liver.

Kupffer cells were isolated by the procedure of Pisano, Filkins, and Di Luzio (1968). Anaesthetized rats were injected with $1000 \mathrm{U}$ heparin into the portal vein and the liver was perfused as above. It was then chopped up and treated with $50 \mathrm{ml}$ of $0.01 \%$ collagenase in Hank's solution, $\mathrm{pH} \mathrm{7.4}$, at $4^{\circ}$ for two hours, then filtered, spun 15 minutes at $300 \mathrm{~g}$, and the pellet washed three times. This was then suspended in $10 \mathrm{ml}$ of $0.005 \%$ trypsin and vigorously shaken for 15 minutes at $37^{\circ}$. The digested mixture was sometimes gelatinous and had to be diluted before being washed and spun on the cytocentrifuge as described by Jones, Torrigiani, and Roitt (1971). Kupffer cells were always contaminated to a variable degree with blood cells. Red blood cells could be removed by brief lysis in distilled water. Leucocytes (WBC) and small numbers of damaged hepatocytes could be recognize $\$$ by the absence of ingested carbon. Slides were stained with May Grünwald Giemsa.

Rat peritoneal macrophages were prepared by the method of Zembala and Asherson (1970). Peritoneal exudate cells harvested four days after intraperitoneal injection of paraffin oil and resuspended in $25 \%$ Ficoll, were placed in $50 \mathrm{SW}$ rotor tubes layered with 21,16 , and $12 \%$ Ficoll in phosphate-buffered saline. After spinning at $20000 \mathrm{~g}$ for 70 minutes macrophages collected at the $12-16 \%$ interface where they constituted $90 \%$ of the cell count. They were washed and cytocentrifuged.

PREPARATION OF RAT WHITE BLOOD CELLS An equal volume of $3.5 \%$ T 250 Dextran (Pharmacia) was added to heparinized blood; after red cell sedimentation the supernatant was aspirated, washed with Hank's solution, and cytocentrifuged. To prepare glass-adherent cells, the method used by Huber and Fudenberg (1968) was employed: जै aliquots of $2 \times 10^{5} \mathrm{WBC}$ were placed in small cups made by sticking glass rings on a slide. They were left at $37^{\circ}$ for one hour, washed three times, and the adherent cells stained by immunofluorescence. Attempts were also made to demonstrate the immunofluorescence on direct suspensions of $\mathscr{D}$ WBCs using aliquots of $10^{7}$ cells $/ \mathrm{ml}$. However, negative sera stained these cells non-specifically and it was not possible to distinguish this from specific staining with the positive sera. 


\section{Results}

\section{FLUORESCENCE APPEARANCES}

This paper will not deal with the immunofluorescence patterns now known to be related to smooth muscle and cellular contractile fibre constituents (Trenchev, Sneyd, and Holborow, 1973) which include the 'hexagonal', 'bile canalicular', 'glomerular', and 'pericellular' fluorescence in other organs.

Two patterns affecting connective tissue fibres can be clearly distinguished and they will be referred to as reticulin $1\left(R_{1}\right)$ and reticulin $2\left(R_{2}\right)$. Sinusoidal cell fluorescence also shows two clear-cut patterns: some sera stain only Kupffer cells and others probably stain blood-borne mononuclear cells adherent to liver sinusoids. However, many sera appear to react with both reticuloendothelial cells and connective tissue fibres or ground substances around the portal tracts and lining the sinusoids. These sera contain a mixture of separate specificities which vary from one serum to the next and have not yet been clearly separated from each other. The most common appearance in this category will be described as the 'sinusoidal' ( $\left.R_{s}\right)$ pattern.

\section{Reticulin $R_{1}$ pattern}

This corresponds with the pattern described by Seah et al (1971a) in coeliac disease. The main

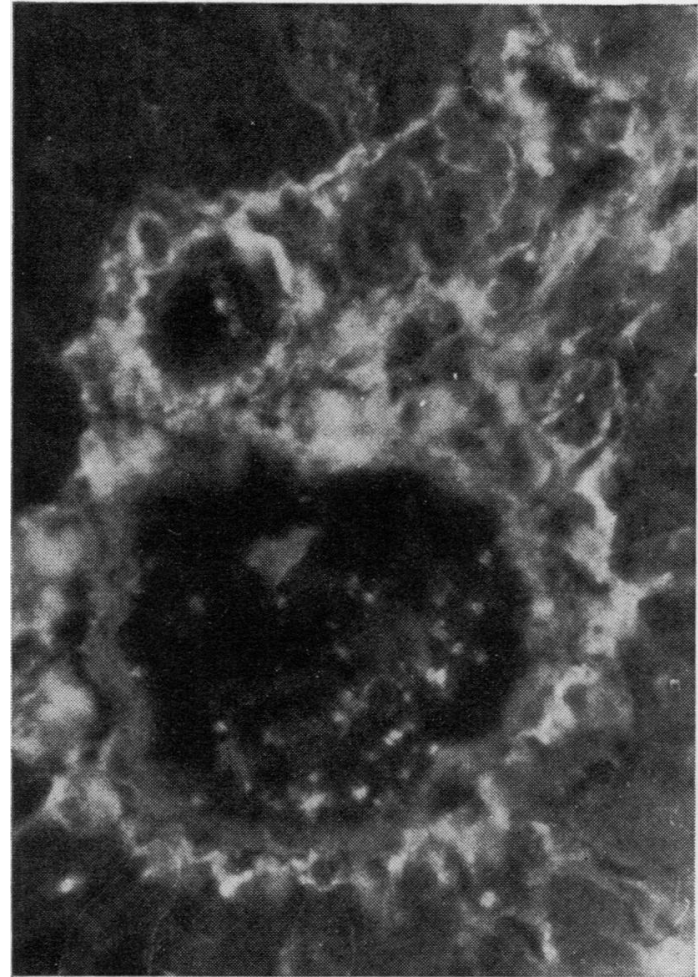

Fig 1

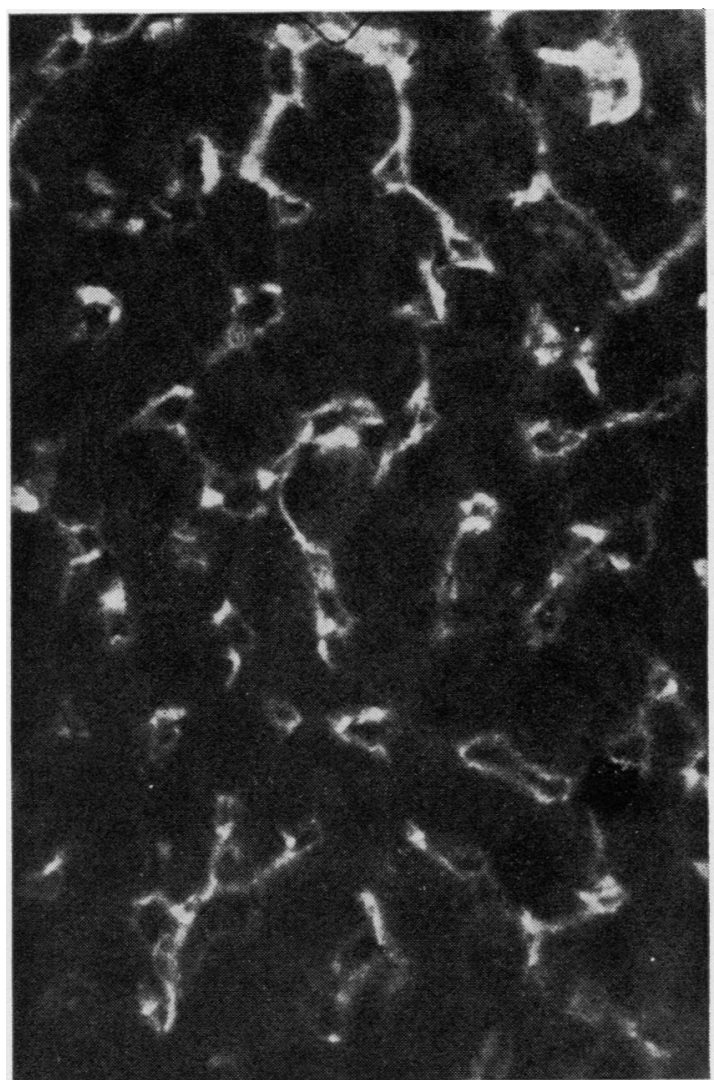

Fig 2

Fig 1 Rat liver showing $R_{1}$ reticulin antibodies. A nodular fluorescenct flls the connective tissue space around the portal tract up to the limiting plate of hepatocytes and soft-edged fibres spread into the sinusoids. Note absence of fluorescence on the thin fibres edging the portal tract.

Fig 2 Same preparation showing $R_{1}$ antibodies on hepatic sinusoids. Note the soft-edged thick fibres cut transversely and appearing as spots, and the fine fluorescence lining the sinusoidal wall. Intrasinusoidal cells are unstained.

Figures 1-11 represent immunofluorescent reactions obtained by treating unfixed $5 \mu$ cryostat sections of rat tissues with patients' sera followed by FITC conjugate of antihuman FAB (magnification $\times 336$ unless otherwise stated). 
features are a 'nodular' or lumpy fluorescence surrounding the portal tracts up to the limiting plate of hepatocytes (fig 1) and a fine outline of sinusoids (fig 2). With high titre reactions there are also discrete, wavy, worm-like strands extending into the sinusoidal walls, while some sera only stain periportal connective tissue. In the kidney $R_{1}$ sera show staining around all tubules (fig 3) and Bowman's capsule. In other organs the same slightly 'nodular' and thick soft-edged fibres are seen surrounding glandular structures and on smooth or striated muscle there is a 'honeycomb' appearance. $R_{1}$ antibodies react with animal and human tissues, giving similar staining patterns in all species tested including foetal rat.

\section{Reticulin $R_{2}$ pattern}

These antibodies were also briefly mentioned by Seah, Fry, Rossiter, Hoffbrand, and Holborow (1971). They reacted only with rat and mouse

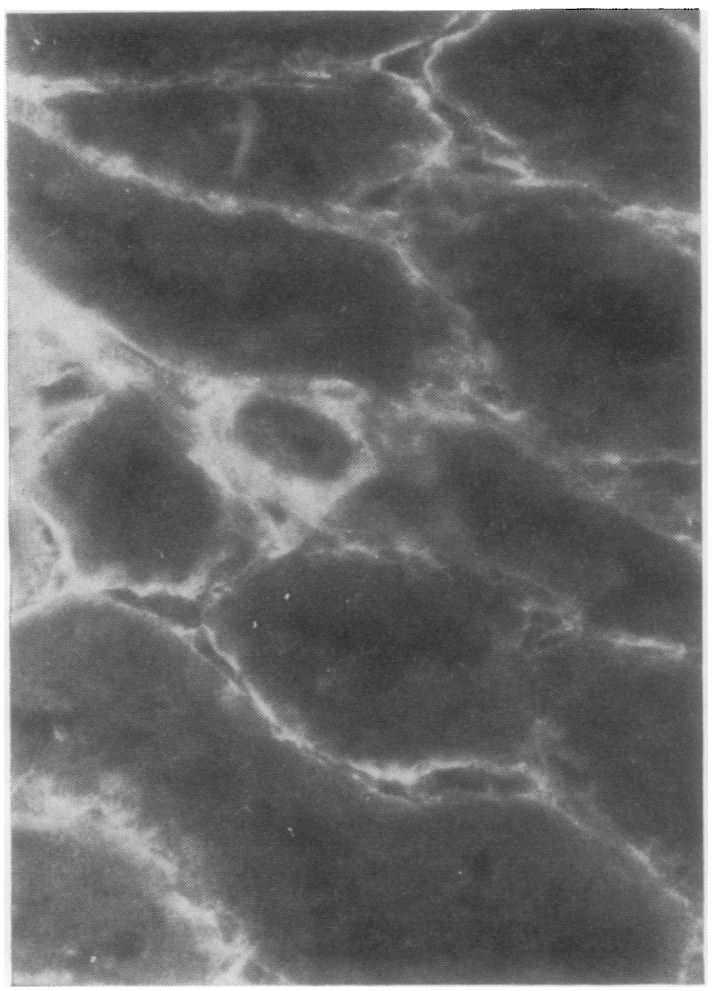

Fig 3 tissues and showed no cross-reaction with human organs or with pig, beef, lamb, or rabbit liver, and foetal rat liver gave negative results. $\mathbf{R}_{2}$ sera stained thin sharp-edged fibres around the portal tracts which did not extend into the liver lobule (fig 4). In stomach when cut longitudinally the fibres appeared as long streaks lying between gastric glands. The muscularis mucosae contained very few of these fibres but they were concentrated around vessels in all organs. The fluorescence outlined the wavy elastic layer and lined the outer surface of arterial muscle (fig 5 ). In the perivascular areolar tissue they appeared as numerous sharp short lines or dots according to whether they were cut transversely or longitudinally. In the kidney there was no staining between tubules or on Bowman's capsule and the perivascular connective tissue was the only stained component. In the liver and between gastric glands the appearance can be mistaken for smooth muscle fluorescence, except

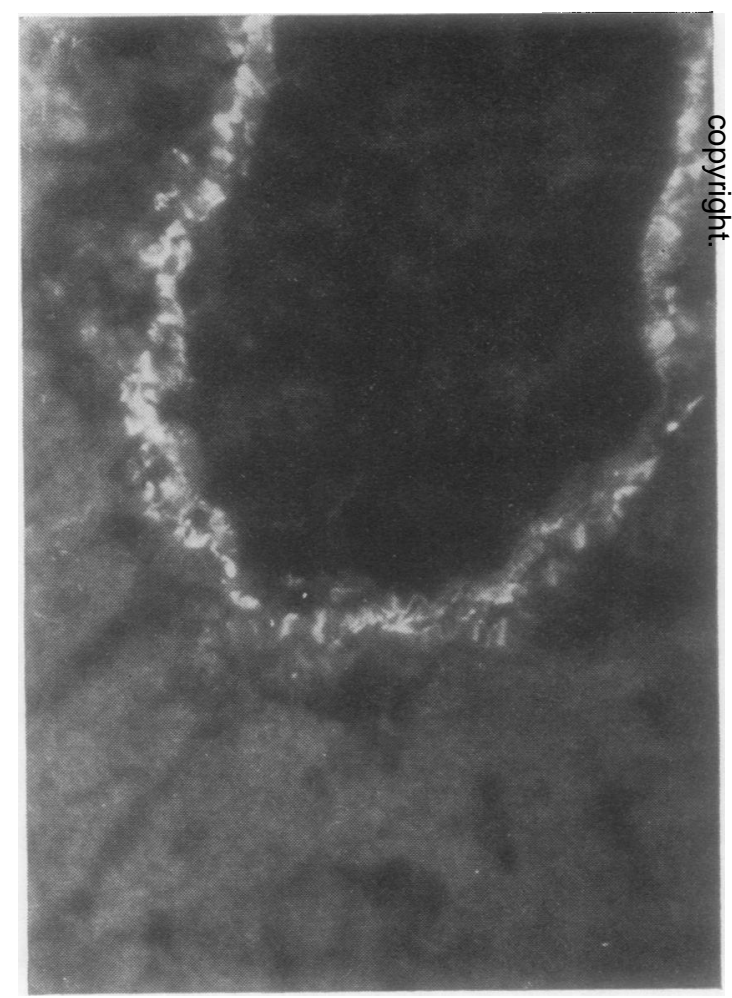

Fig 4

Fig 3 Same $R_{1}$ serum on rat kidney soft-edged fluorescence around all renal tubules. Small artery in centre shows fluorescence only in the perivascular connective tissue.

Fig $4 R_{2}$ reticulin fluorescence on rat liver showing sharp thin fibrils at edge of portal tract only. No staining in the loose areolar reticulin extending out to the hepatic lobule. 


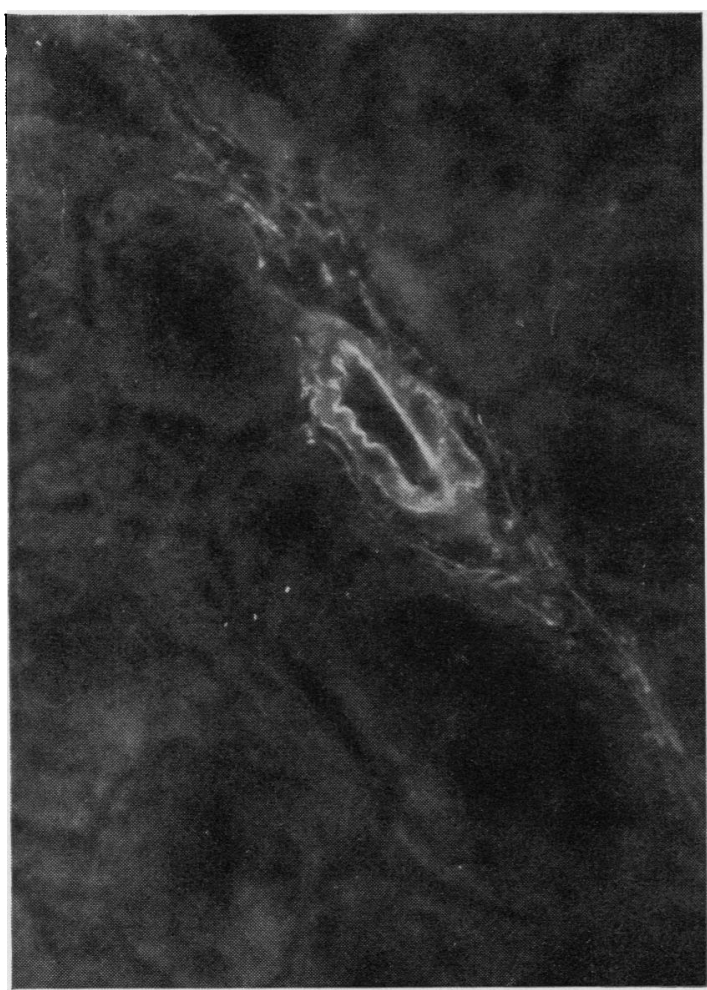

Fig $5 R_{2}$ fluorescence on rat kidney. Staining is confined to thin long perivascular fibres and outlines the vascular endothelium and the outer edge of the muscle layer. There is no fluorescence around the tubules.

that the $\mathbf{R}_{\mathbf{2}}$ fibres are very thin and sharper than smooth muscle fibres.

\section{Kupffer cell fluorescence (KC)}

With such sera, fluorescence was limited to isolated large sinusoidal cells of irregular shape and size, randomly distributed throughout the liver (fig 6). Endothelial cells, portal tracts, and connective tissue fibres were negative. No decrease in the number of positive cells was observed when using extensively perfused livers. After carbon loading fluorescence was observed in swollen, heavily loaded cells as seen by the alternate use of phase contrast and fluorescent lighting. Carbon loading diminished the fluorescence and displaced it to the edge of the cells. Other sinusoidal cells containing small carbon grains were unstained. Isolated cytocentrifuged Kupffer cells showed bright uniform cytoplasmic staining (fig 7). To exclude reaction of the human sera with possible immune complexes phagocytosed in the rat in vivo, sections were treated with a direct FITC conjugate of rabbit anti-rat serum, and no staining of the Kupffer cells or sinusoids was seen.

In the spleen, staining with Kupffer cell sera was confined to clusters and short rows of irregular polygonal cells which were heavily loaded in carbontreated animals and were situated in the cortex (fig 8). Thymus and lymph node sections, pulmonary alveolar macrophages, peritoneal macrophages, and buffy coat smears were negative with Kupffer cell sera. Kupffer cell immunofluorescence could be demonstrated in rat, mouse, and rabbit tissues but not in human, pig, beef, and sheep liver.

4 Sinusoidal adherent cell cytoplasmic immunofluorescence $(A C)$

This pattern was observed in a limited number of cases. Fluorescence was confined to the cytoplasm

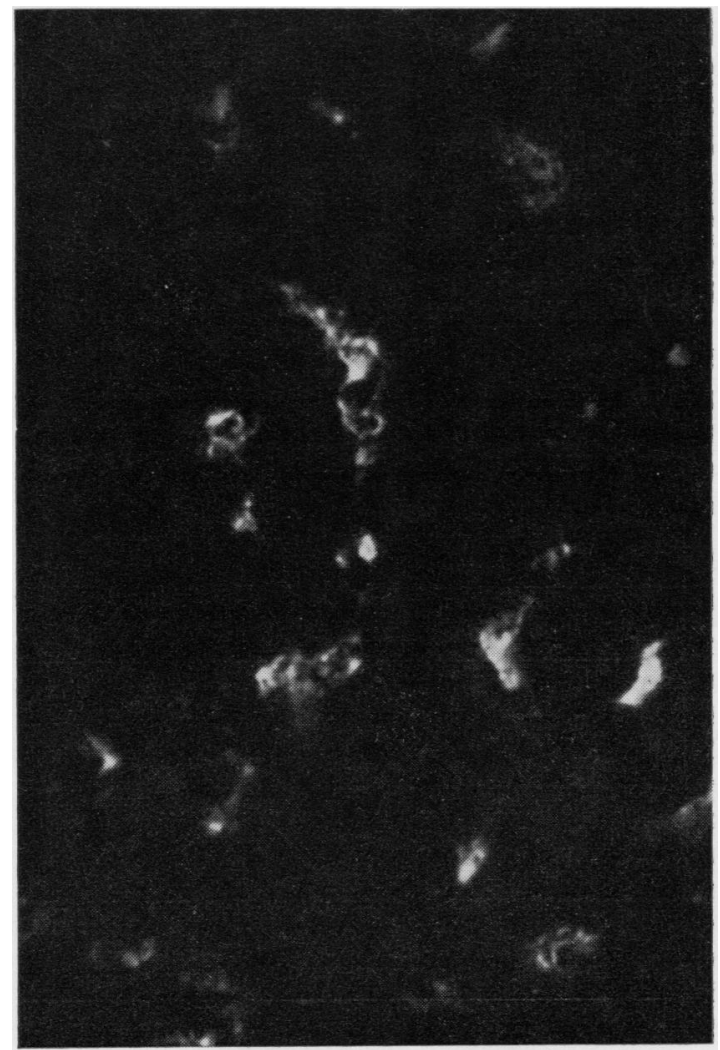

Fig 6 Carbon-loaded rat liver showing Kupffer cell fluorescence. The stained cells are of varying size and shape and contain large granules of ingested carbon which can be seen in the cytoplasm and are surrounded by a rim of fluorescence. 


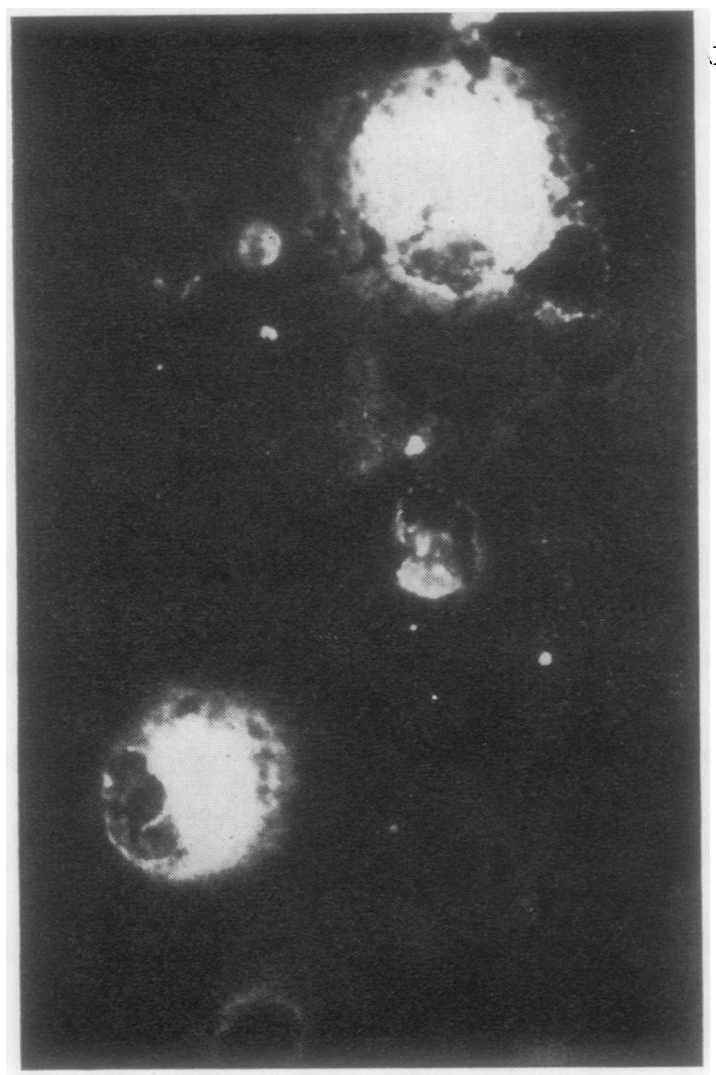

Fig 7

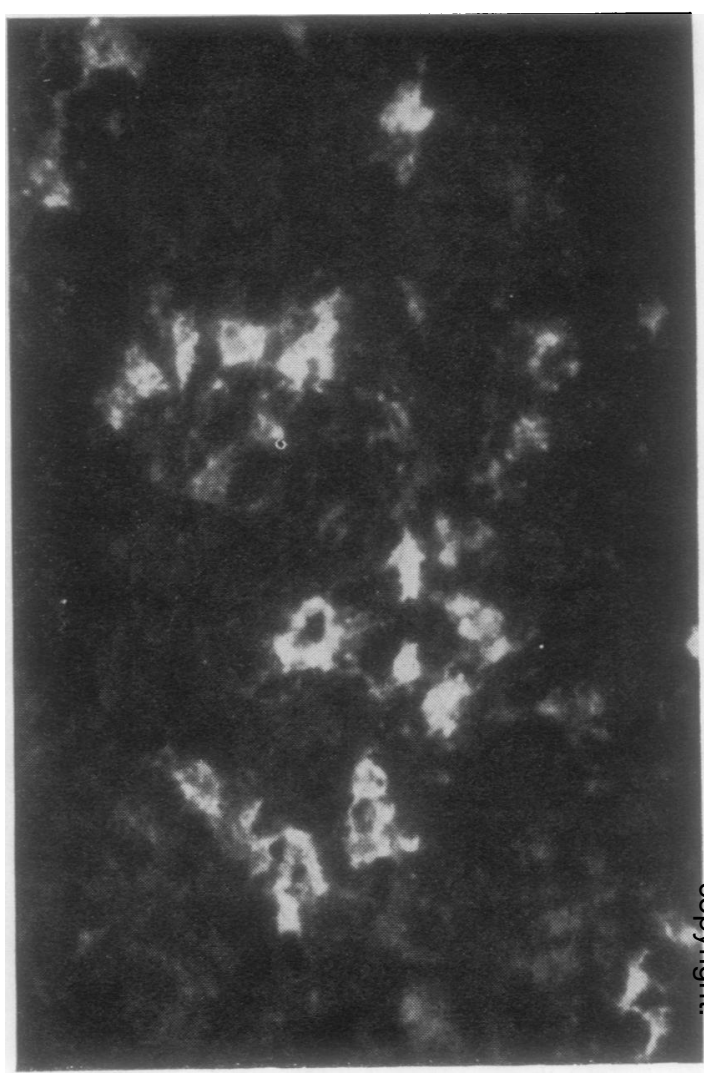

Fig 8

Fig 7 Isolated rat Kupffer-cell cytocentrifuge spread treated with a Kupffer cell serum, showing diffuse cytoplasmic fluorescence. Carbon particles gravitate to the periphery of the cells in this type of preparation $(\times 400)$.

Fig 8 Rat spleen stained with a Kupffer cell $(K C)$ serum showing a ridge of large irregular fluorescent cells in the cortex.

of small rounded cells, irregularly distributed through the liver (fig 9). The number of positive cells did not appear to decrease after prolonged liver perfusion. After intraperitoneal carbon injection, more than half $(50-70 \%)$ the positive cells showed discrete granular cytoplasmic carbon deposits, while in other similar cells no black granules could be seen when the light was switched from fluorescence to phase contrast. Kupffer cells were non-reactive. A few cells reacting with AC sera were also seen in rat stomach, ileum, and colon. When isolated peritoneal macrophages were tested 50-70\% were fluorescent to a variable degree; the staining was strongest in the perinuclear region (fig 10). Whole buffy coat cytocentrifuged preparations and suspensions of viable WBCs showed a large number of non-specifically stained polymorphs but some additional staining of mononuclear cells could be seen with positive sera. When adherent circulating mononuclear cells were selected, the great majority (more than $80 \%$ ) were brightly stained with AC sera and were distinctly less fluorescent when negative control or Kupffer cell sera were applied. Apart from adult and foetal rat, mouse and rabbit were reactive with AC sera whereas no staining was obtained with human organs, and pig, beef, and sheep liver.

\section{Reticulin sinusoidal fluorescence patterns $\left(\boldsymbol{R}_{\mathrm{S}}\right)$}

The majority of patients giving reticulin connective tissue immunofluorescence on rat liver fell into this mixed group. The common feature was a diffuse staining of the sinusoids associated with cytoplasmic staining of Kupffer and other reticuloendothelial cells (fig 11). Many of the sera gave periportal fluorescence resembling reticulin $R_{1}$ and less 


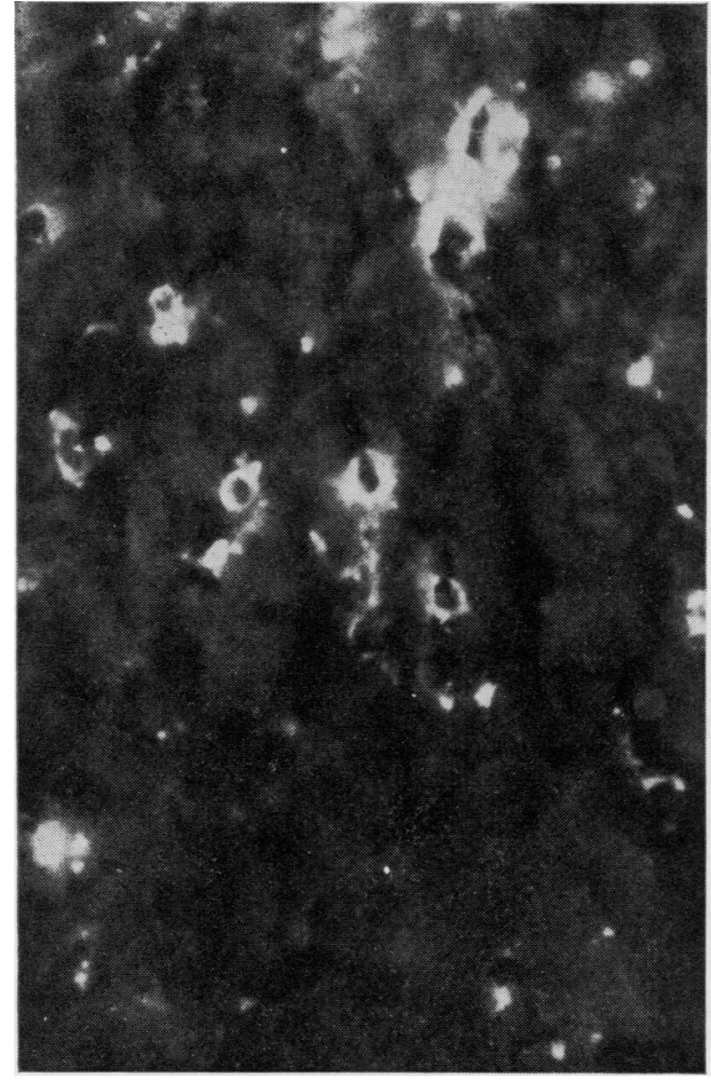

Fig 9

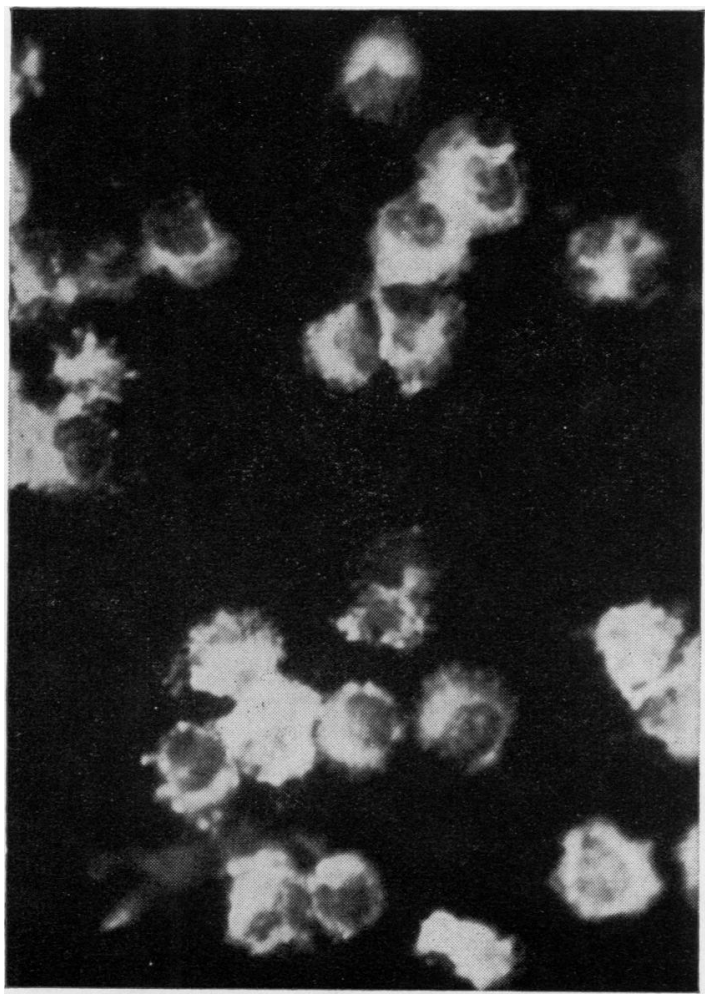

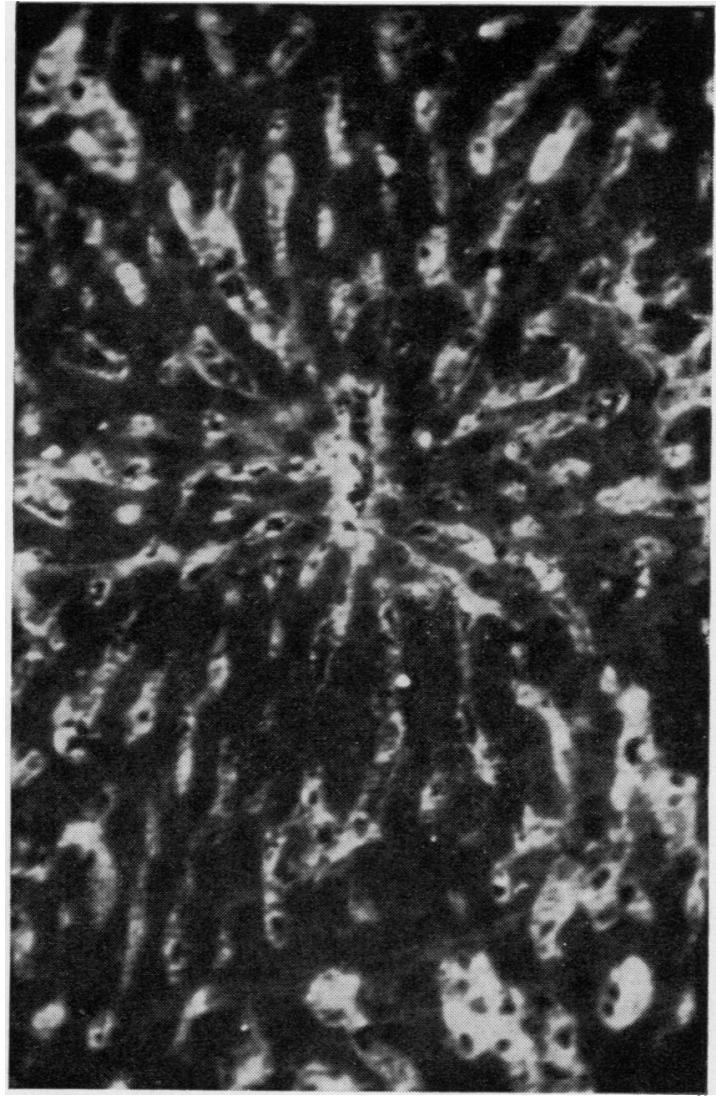

Fig 11

Fig 9 Rat liver treated with a serum containing antibodies to glass adherent blood mononuclear cells $(A C)$. The cells are smaller and of more uniform shape than Kupfer cells. Large blob (top centre) is probably an artefact.

Fig 10 Isolated rat peritoneal macrophages stained with same AC serum. The cytoplasmic fluorescence is strongest around the nucleus.

Fig 11 Rat liver treated with a serum giving the complex reticulin $R_{\mathrm{s}}$ pattern. The fluorescence can be seen lining the hepatic sinusoids, and several varieties of intrasinusoidal reticuloendothelial cells are stained. Note in particular groups of stained cells at top left and bottom right corners $(\times 186)$ 
frequently $R_{2}$ in addition, but some sera were completely negative on portal tracts while outlining all sinusoids clearly. There were other sera which stained Kupffer cells and other sinusoidal cells but did not react with intrasinusoidal fibres or ground substance. In other organs these $\mathbf{R}_{\mathrm{S}}$ sera produced a variety of appearances. About $20 \%$ stained the rat kidney with the typical $R_{1}$ peritubular pattern. Nearly $50 \%$ had 'brush border' fluorescence on proximal tubules (Ireton, Muller, and McGiven, 1971). Two high-titre sera (Si and Sa) were studied in some detail. Neither stained kidney or stomach. Both gave strong fluorescence on isolated peritoneal macrophages. With carbon-loaded liver, both Kupffer and other sinusoidal phagocytes (? endothelial cells) were stained. On buffy coat smears these sera stained mononuclear cells as with adherent cell sera. In spleen sections clusters of large reticular cells were fluorescent as with sera containing Kupffer cell antibodies. Thymus and lymph node showed isolated large bright cells. In lung sections alveolar walls contained occasional fluorescent round cells. The distribution of reactivity of the different RE cells with Kupffer cell, adherent cell, and $R_{S}$ sera are shown in table II. The species reactivity and relative frequency of these antibodies are shown in table III.

Weak reactions of the $R_{S}$ type must be interpreted with caution as sometimes the control sections stained only with anti-gamma or anti-IgG conjugates show a faint fluorescence of sinusoidal walls, without cytoplasmic staining of reticuloendothelial cells.

Two absorption experiments were made with rat albumin bought commercially and rat serum globulins obtained by $40 \%$ ammonium sulphate precipitation. These serum proteins were coupled to glutaraldehyde by the method of Avramase and Ternynck (1969) to make them insoluble. The albumin had no effect $(20 \mathrm{mg} / \mathrm{ml})$ but $4 \mathrm{mg} / \mathrm{ml}$ of globulins removed all the fluorescence.

\section{IMMUNOLOGICAL CHARACTERISTICS OF}

MESENCHYMAL ANTIBODIES

The antibodies giving the five fluorescence patterns described above were of IgG class and non-complement fixing. The titres were mostly low, 20-80. Reticulin $R_{1}$ and $R_{2}$ antibodies were occasionally of high titre up to 640 . With sinusoidal $R_{s}$ patterns it was difficult to determine the endpoint in view of the background produced by conjugates but definite positive reactions were seen up to titres of 160 .

Most of the antigens involved resisted fixation with cold acetone and ether for 10 and 30 minutes. The $R_{1}$ pattern withstood methanol for 10 minutes but this substantially diminished or abolished all the other patterns as did formalin and glutaraldehyde.

\section{CLINICAL ASSOCIATIONS OF MESENCHYMAL} IMMUNOFLUORESCENCE

The overall incidence in different disease groups of the five patterns described is shown in table I. Dermatitis herpetiformis and coeliac disease showed a higher incidence of all the patterns than any other group. Chronic heroin addicts also had a significantly increased incidence $(20 \%)$. With the exception of rheumatoid arthritis and Sjögren's syndrome, all other disease groups in which a sufficient number of

\begin{tabular}{|c|c|c|c|c|c|}
\hline \multirow{2}{*}{$\begin{array}{l}\text { Fluorescence Pattern } \\
\text { Obtained with Serum }\end{array}$} & \multicolumn{2}{|l|}{ Liver Sinusoids } & \multirow{2}{*}{$\begin{array}{l}\text { Glass-adherent } \\
W B C\end{array}$} & \multirow{2}{*}{$\begin{array}{l}\text { Peritoneal } \\
\text { Macrophages }\end{array}$} & \multirow{2}{*}{$\begin{array}{l}\text { Lung Alveolar } \\
\text { Macrophages }\end{array}$} \\
\hline & $\begin{array}{l}\text { Large Phago- } \\
\text { cytic Cells }\end{array}$ & $\begin{array}{l}\text { Small Phago- } \\
\text { cytic Cells }\end{array}$ & & & \\
\hline Kupffer cell (KC) & $\div$ & - & - & - & - \\
\hline 'Adherent' cell (AC) & - & + & + & $50-70 \%$ & \pm \\
\hline Sinusoidal fibres and cells ( $\boldsymbol{R}_{\mathrm{s}}$ ) & 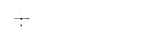 & $\cdots$ & + & + & + \\
\hline
\end{tabular}

Table II Immunofluorescence with reticuloendothelial cells of different types

\begin{tabular}{|c|c|c|c|c|c|c|c|c|c|}
\hline \multirow[t]{2}{*}{ Type of Reacting Fibres/Cells } & \multirow{2}{*}{$\begin{array}{l}\text { Percentage Strong }( \\
\text { Reactions in } 8000 \text { Sera }\end{array}$} & \multirow[t]{2}{*}{ Human } & \multirow[t]{2}{*}{ Pig } & \multirow[t]{2}{*}{ Beef } & \multirow[t]{2}{*}{ Sheep } & \multicolumn{2}{|l|}{ Rat } & \multirow[t]{2}{*}{ Mouse } & \multirow[t]{2}{*}{ Rabbit } \\
\hline & & & & & & Adult & Foetal & & \\
\hline Thick reticulin fibres $\left(R_{1}\right)$ & $0 \cdot 25$ & + & + & + & + &. & $\therefore$ & + & + \\
\hline Thin reticulin fibres $\left(\mathbf{R}_{\mathbf{2}}\right)$ & $0 \cdot 35$ & - & - & - & - & $\cdots$ & $\cdots$ & + & - \\
\hline \multicolumn{10}{|l|}{ Intrasinusoidal fine fibres and } \\
\hline $\mathrm{AC} / \mathrm{KC}\left(\mathbf{R}_{\mathrm{s}}\right)$ & $0 \cdot 60$ & - & - & - & - & $\cdots$ & $\cdots$ & + & + \\
\hline Kupffer cell cytoplasm (KC) & $0 \cdot 20$ & - & - & - & - & $\therefore$ & + & + & + \\
\hline 'Adherent' cell cytoplasm ( $A C$ ) & $0 \cdot 10$ & - & - & - & - & + & $T$ & + & + \\
\hline
\end{tabular}

Table III Relative incidence and species reactivity of mesenchymal immunofluorescence patterns 
sera were available for testing, including patients with drug hypersensitivities, showed an incidence which did not differ significantly from that of healthy controls. The antibodies were not prevalent in liver disorders, and no correlation could be shown with autoimmunity. In thyroid diseases, there was a slightly higher prevalence in autoimmune cases than in other goitres but the titres were unimpressive.

The relative frequency of each fluorescence pattern could only be assessed accurately with strongly reacting sera $(++)$. This is shown in table III and varied from $0 \cdot 1 \%$ for the adherent cell pattern to $0.6 \%$ for the sinusoidal $R_{s}$ fluorescence out of 8000 sera assessed in this way. If weaker $(+)$ reactions were counted, the frequency of each pattern was about three times higher.

No systematic follow up has been made to study the persistence of these antibodies in individual cases with a few exceptions: one patient with rheumatoid arthritis has had a high titre of the $\mathbf{R}_{\mathbf{S}}$ pattern for five years to our knowledge and a cardiac patient with $R_{1}$ pattern was followed for a year with no evidence of decrease. One interesting case showed a Kupffer cell fluorescence to a titre of $\mathbf{3 2 0}$ soon after an episode of serum sickness which followed an antitetanus injection. On repeated testing for 10 months the titres gradually declined and the antibodies disappeared. The fluorescence could not be absorbed out with antitetanus horse gamma globulin. Another patient had the adherent cell pattern following myocardial infarction and the reaction gradually became negative after six months.

\section{Discussion}

The connective tissue elements shown up by silver reticulin stains or PAS are a complex mixture of amorphous proteins and mucopolysaccharides constituting the ground substances in which there is a network of fibrous proteins related to collagen in all stages of maturation, ranging from the microfibrils secreted by fibroblasts, and only seen by electron microscopy, to the tri-helical fibrils with $640 \AA$ periodicity which undergo progressive crosslinking until they grow into adult collagen fibres (Popper and Udenfriend, 1970). Adult collagen itself is stained by Van Giesson, Mallory, and Masson's trichrome but not by reticulin stains. There are a large number of chemically distinct compounds which are antigenic in animals (Steffen, Timpl, and Wolf, 1968) and may evoke immune reactions in patients (Steffen, 1969).

At least two quite different fibrillary antibodies demonstrable by immunofluorescence exist in human sera which we have called $R_{1}$ and $R_{2}$. The fibres giving these two patterns differ in their appearance, anatomical distribution, and species specificity. The $R_{1}$ fibres are soft edged and the fluorescence resembles reticulin stained by PAS. The $\mathbf{R}_{\mathbf{2}}$ fluorescence picks up sharp thin fibres which probably form part of what is seen with silver reticulin stains. Neither of these fibres is related to procollagen soluble in acid or neutral salts (Steffen, 1965), since sera (kindly supplied by Professor Steffen) known to have high titres of antibodies reacting in the globulin consumption test with soluble collagen preparations gave negative results for $R_{1}$ and $R_{2}$ reticulin immunofluorescence. Pras, Johnson, Holborow, and Glynn (1973) isolated a reticulin component from pig kidney and reported that antibodies produced in rabbits gave a similar immunofluorescence pattern to that seen with sera from coeliac patients and corresponding to our $R_{1}$ nomenclature. The fluorescence of the sinusoidal walls seen in some $R_{1}$ sera and all $R_{s}$ sera is more difficult to localize to defined structures, and resolution at the electron microscope level will be required to see if the antigens are fibrillary or belong to the components of ground substance.

The Kupffer cell pattern is readily distinguished by the shape and size of the fluorescent cells and by their heavy carbon loading (Widmann, Cotran, and Fahimi, 1972). Related large fluorescent cells are also seen in the spleen. The 'adherent cell' pattern seems to be produced by antibodies directed against mononuclear cells in the sinusoids which take up smaller carbon particles and cannot be dislodged by exhaustive liver perfusion. The fact that 'adherent cell' sera also stain peritoneal macrophages and circulating glass-adherent WBC suggests that the sinusoidal small phagocytes are in fact derived from blood (Greenberg, Shen, and Roitt, 1973). We do not know whether any sera react with fat-storing fibroblasts (Ito and Shibasaki, 1968), and the existence of small non-phagocytic pericytes as described by Tanikawa, Yoshimura, and Gohara (1965) is doubted by many authors who call these cells 'lymphocytes'. Sinusoidal endothelial cells are too numerous to be the cells stained by 'adherent cell' sera, although the small carbon particles seen in the fluorescent cells shown by these sera would be of suitable appearance for sinusoidal endothelial cells (Widmann et al, 1972).

The sinusoidal reticulin $\mathbf{R}_{\mathrm{S}}$ immunofluorescence represents a mixture of antibodies reacting with several types of hepatic sinusoidal cells and with extracellular material lining the space of Disse. These sera give variable patterns in other rat organs, which also suggests the simultaneous presence of several antibodies. Twenty per cent of them contain fibrillary $R_{1}$ antibodies as seen from their staining of 
renal peritubular connective tissue. A common feature of the $R_{s}$ sera is their reaction with both extra- and intracellular materials, and the question of whether there are common antigens in the mesenchymal matrix and the cytoplasm of these cells is of interest. Radioactive studies suggest that hydroxyproline appears extra- and intracellularly during sinusoidal fibroplasia following carbon tetrachloride poisoning in rats suggesting common antigens (Huberman, Recio, Rojkind, and White, 1969). The nature of the sinusoidal cells fluorescing with $\mathrm{R}_{\mathrm{s}}$ sera has been investigated with two high-titre sera. These stained both purified Kupffer cells and isolated peritoneal macrophages. Some sera placed in this mixed group appeared to stain many more sinusoidal cells than Kupffer and 'adherent' cell sera put together. This suggests that human sera may sometimes contain antibodies against sinusoidal endothelium. If the patterns seen in liver and other organs with $\mathrm{R}_{\mathrm{S}}$ sera indicate a variable mixture of distinct antibodies, this is analogous to the situation in smooth muscle fluorescence. The work of Trenchev et al (1973) suggests that fluorescent patterns produced by patients' sera are due to a mixture of closely related antibodies to several smooth muscle proteins. Fifty per cent of $\mathrm{R}_{\mathrm{S}}$ sera also contained heterologous antibodies seemingly unrelated to connective tissue, as, for instance, brush-border fluorescence in rat proximal renal tubules.

We have confirmed that reticulin antibodies as a group are more prevalent in coeliac disease and dermatitis herpetiformis as described by previous authors (Seah et al, 1971a and b, 1973: Alp and Wright, 1971; Ammann and Hong, 1971; von Essen, Savilahti, and Pelkonen, 1972). All the patterns described in the present paper can be seen in sera from these patients. In addition to Crohn's disease studied by Alp and Wright (1971), the only other group of patients showing a raised incidence were longstanding heroin addicts and possibly rheumatoid arthritis and Sjögren cases. Examination of very extensive material from autoimmune disorders and drug hypersensitivities does not suggest an increase of reticulin antibodies. Liver cirrhosis, whether or not associated with autoimmune phenomena, is equally free of this type of reaction, despite the very marked stimulation of the reticuloendothelial system in these diseases (Popper and Udenfriend, 1970: Triger and Wright, 1973). In coeliac disease it has been shown that reticulin antibodies tend to disappear when a gluten-free diet is adopted (Seah et al, 1971b). It has also been shown (Shiner and Ballard, 1972) that antigen/ antibody complexes are deposited on the jejunal basement membrane in the untreated disease or on challenge with gluten. There are close chemical relationships between basement membrane components and ground substances (Spiro, 1973), but the connexion with gluten antigens is at present obscure. The raised incidence of reticulin antibodies in heroin addicts who are exposed to numer ous injected bacterial antigens and in malabsorption where bacterial and food antigens penetrate the gut more easily suggests some connexion with microorganisms. The staining of Kupffer cells demonstrated by Kingston and Glynn (1971) with experimental antistreptococcal sera is relevant in this context.

The transient high titres of reticulin antibodies found in cases of horse-serum anaphylaxis and following myocardial infarction suggest that these antibodies are anamnestic reactions rather than actual bacterial antibodies cross-reacting with reticulin components. The lack of correlation with the genetically determined types of autoimmunity, ie, thyroiditis, gastritis, and adrenalitis, bring the reticulin group of antibodies closer to smooth muscle and nuclear antibodies, which are more easily evoked by external agents, particularly viruses and drugs (Holborow, 1972; Doniach, 1972).

The fact that $R_{1}$ reticulin antibodies react with human tissues while the other patterns can only be demonstrated in a restricted number of species is in keeping with what is known of other heter-ect ologous antibodies found in human sera. The question of why certain antibodies are polarized to certain diseases which appear unrelated to the particular tissue evoking the antibodies is still one of the unanswered problems in autoimmunity.

We wish to thank Dr Simon Ardeman for specimens from a patient with serum sickness.

We are grateful to the many physicians who sent sera from their patients for antibody tests and to Professor I. M. Roitt for his support.

We thank Mr and Mrs G. Swana for their excellent technical assistance and Miss J. Richardson for help with the manuscript.

Work in the Department of Immunology is supported by the Medical Research Council and the World Health Organziation.

References

Alp, M. H., and Wright, R. (1971). Autoantibodies to reticulin in patients with idiopathic steatorrhoea, coeliac disease and Crohn's disease, and their relation to immunoglobulins and dietary antibodies. Lancet, 2, 682-685.

Ammann, A. J., and Hong, R. (1971). Unique antibody to basement membrane in patients with selective IgA deficiency and coeliac disease. Lancet, 1, 1264-1266.

Avrameas, S., and Ternynck, T. (1969). The cross-linking of proteins with gluteraldehyde and its use for the preparation of immunoadsorbents. Immunochemistry, 6, 53-66.

Doniach, D. (1972). Autoimmunity in liver diseases. Progr. clin. Immunol., 1, 45-70.

von Essen, R., Savilahti, E., and Pelkonen, P. (1972). Reticulin 
antibody in children with malabsorption. Lancet, 1. 1157-1159.

Greenberg, A. H., Shen, L., and Roitt, I. M. (1973). Characterization of the antibody dependant cytotoxic cell: a non-phagocytic monocyte? Clin. exp. Immunol., 15, in press.

Holborow, E. J. (1972). Smooth-muscle autoantibodies, viral infections and malignant disease. Proc. roy. Soc. Med., 65, 481484.

Huber, H., and Fudenberg, H. H. (1968). Receptor sites of human monocytes for IgG. Int. Arch. Allergy. appl. Immunol., 34, 18-31.

Huberman, A., Recio, A., Rojkind, M., and White, A. (1969). Collagen biosynthesis in normal and cirrhotic rat liver slices. Proc. Soc. exp. Biol. (N.Y.), 131, 200-203.

Ireton, H. J. C., Muller, H. K., and McGiven, A. R. (1971). Human antibody against rat gastric parietal cells and kidney brush border. Clin. exp. Immunol., 8, 783-789.

Ito, T., and Shibasaki, S. (1968). Electron microscopic study on the hepatic sinusoidal wall and the fat-storing cells in the normal human liver. Arch. histol. jap., 29, 137-192.

Jones, G., Torrigiani, G., and Roitt, I. M. (1971). Immunoglobulin determinants on mouse lymphocytes. J. Immunol., 106, 1425-1430.

Kingston, D., and Glynn, L. E. (1971). A cross-reaction between Str. pyogenes and human fibroblasts, endothelial cells and astrocytes. Immunology, 21, 1003-1016.

Pisano, J. C., Filkins, J. P., and DiLuzio, N. R. (1968). Phagocytic and metabolic activities of isolated rat Kupffer cells. Proc. Soc. exp. Biol. (N.Y.), 128, 917-922.

Popper, H., and Udenfriend, S. (1970). Hepatic fibrosis: correlation of biochemical and morphologic investigations. Amer. $J$. Med., 49, 707-721.

Pras, M., Johnson, G. D., Holborow, E. J., and Glynn, L. E. (1973). The antigenic properties of a reticulin. (Paper given at B.S.I. meeting, April, 1973.)

Seah, P. P., Fry, L., Hoffbrand, A. V., and Holborow, E. J. (1971a). Tissue antibodies in dermatitis herpetiformis and adult coeliac disease. Lancet, 1, 834-836.
Seah, P. P., Fry, L., Rossiter, M. A., Hoffbrand, A. V., and Holborow, E. J. (1971b). Anti-reticulin antibodies in childhood coeliac disease. Lancet, 2, 681-682.

Seah, P. P., Fry, L., Holborow, E. J., Rossiter, M. A., Doe, W. F., Magalhaes, A. F., and Hoffbrand, A. V. (1973). Antireticulin antibody: incidence and diagnostic significance. Gut, 14, 311-315.

Shiner, M., and Ballard, V. (1972). Antigen-antibody reactions in jejunal mucosa in childhood coeliac disease after gluten challenge. Lancet, 1, 1203-1205.

Spiro, R. G. (1973). Biochemistry of the renal glomerular basement membrane and its alterations in diabetes mellitus. New Engl. J. Med., 288, 1337-1342.

Steffen, C. (1965). Antigenicity and autoantigenicity of collagen. Ann. N.Y. Acad. Sci., 124, 570-585.

Steffen, C. (1969). Tissue antibodies in rheumatoid arthritis and other connective tissue diseases. Ann. Immunol, 1, 47-58.

Steffen, C., Timple, R., and Wolff, I. (1968). Immunogenicity and specificity of collagen. V. Demonstration of three different antigenic determinants on calf collagen. Immunology, 15, 135-144.

Tanikawa, K., Yoshimura, K., and Gohara, S. (1965). Fine structure of the reticuloendothelial cells in the normal rat liver; morphological classification. Kurume med. J., 12, 139-147.

Trenchev, P., Sneyd, P., and Holborow, E. J. (1973). In Tracing of smooth muscle contractile protein antigens in tissues other than smooth muscle. Clin. exp. Immunol, in press.

Triger, D. R., and Wright, R. (1973). Hyperglobulinaemia in liver disease. Lancet, 1, 1494-1496.

Widmann, J. J., Cotran, R. S., and Fahimi, H. D. (1972). Mononuclear phagocytes (Kupffer cells) and endothelial cells: Identification of two functional cell types in rat liver sinusoids by endogenous peroxidase activity. J. Cell Biol., 52, 159-170.

Zembala, M., and Asherson, G. L. (1970). The rapid purification of peritoneal exudate macrophages by ficoll (polysucrose) density gradient centrifugation. Immunology, 19, 677-681. 